\author{
LACZKó Mária \\ Kaposvári Egyetem \\ ÉSZC Eötvös József Szakgimnázium \\ laczkoma@gmail.com
}

\title{
A BESZÉD JELLEMZÖI SPONTÁN TÁRSALGÁSBAN ÉS TANÓRAI MEGNYILATKOZÁSOKBAN
}

\section{Bevezetés}

A beszéd köztudottan a kommunikáció legtermészetesebb formája valamennyi életkorban, így a különböző életkorú iskolások körében is. Nyelvészeti aspektusból különböző beszédhelyzeteket és ennek megfelelően beszédtípusokat különítünk el (Wacha 1974). Az interpretatív közlésben kötött a mondanivaló és a nyelvi forma, hiszen ebben az esetben a más(ok) által megírtak meghangosítása történik. Ám a megszólaltatás mindig az adott szituációban zajlik, ezzel a spontán beszéd illúzióját keltve. A felolvasás a mások által megfogalmazott/ leírt szöveg későbbi elmondása. Ekkor tehát a szövegalkotás (akció) és a szövegmondás ([re] produkció) időbeli különbsége áll fenn. A félreproduktív beszéd az élőszó igényével jelenik meg, alapja az előadó által megfogalmazott/megírt szöveg. A gondolkodás, a szöveg megalkotása (akció) tehát néha megelőzi a szövegmondást (produkció), néha azzal egy időben, szimultán módon zajlik. A szorosabb értelemben vett élőszó a spontán beszéd. Ekkor a gondolkodás és a szöveg megalkotása, a mondatok megkonstruálása (akció) és elmondása (a produkció) szinkron tevékenység (Wacha 1974). Levelt definíciója alapján a spontán beszédben a meghangosítani szándékozott gondolatokat, a hozzájuk tartozó nyelvi formát és az artikulációt egyaránt megtervezzük, s mindezek közel egy időben zajló folyamatok a beszélő számára (Levelt 1989). Éppen ezért a spontán beszéd nem folyamatos, a különböző beszédtervezési szinteken fellépő diszharmonikus jelenségek szakítják meg a folyamatosságot (Postma et al. 1990; Harley 2001; Shriberg 2001; Nooteboom 2005). Néhány kutatás azonban éppen ellenkezőleg azt hangsúlyozza, hogy vannak olyan diszharmonikus jelenségek (pl. a nyújtás vagy az ismétlés), amelyek nem szakítják meg a folyamatosságot, hanem éppen azt biztosítják (Gyarmathy 2009).

E diszharmonikus jelenségek összefoglaló neve a megakadásjelenség, amelyeknek többféle kategorizációja létezik, ám a magyar szakirodalomban a felszíni szerkezetből kiinduló felosztásban a bizonytalanságok és a hibák típusát különítik el (Gósy 2002). A spontán beszéd tervezési műveleteinek és artikulációs műveleteinek szinkron működéséből adódóan tehát a folyamatosságot a beszélő bizonytalanságát jelző ismétlés, nyújtás, újraindítás, a jellel kitöltött szünet (hezitálás), a szó belsejében tartott szünet vagy a töltelékszó törheti meg, míg a hibák között a sorrendiséggel kapcsolatosak (anticipációk, perszeverációk, kontaminációk, metatézisek), grammatikai hibák, téves szók/szókezdetek említendőek. 
Az iskolai keretek között a tanulók megnyilatkozásai bár sokfélék lehetnek, számos tényező alakítja e formákat. Így például a személyi tényezők (pl. a pedagógus személyisége, beszédkultúrája, szakmai és módszertani kultúrája, gyakorlottsága, a tanulók jellemzői, a tanulók és a pedagógusok kapcsolata) mellett számolnunk kell a dologi tényezők (a tananyag, a tanóra nevelési-oktatási céljai, didaktikai feladatai, az osztályterem stb.) hatásával is (Antalné 2003, 2006). Az iskolai kommunikációs helyzetekben a tanulók leggyakoribb megnyilatkozási formái között tartjuk számon a kérdést/ kérdezést, a tanári kérdésre adott hosszabb/rövidebb válaszokat, a tanulói utasításokat, a képről alkotott szövegeket, események, cselekmények elmesélését, a disputát/vitaindítókat, kiselőadást, projektmunkáról történő beszámolót stb. Valamennyi megnyilatkozási formát számba véve a leggyakrabban a feleltetéssel, a felelettel találkozunk. A szóbeli felelet mint a szóbeli számonkérés formája sok esetben egy téma önálló kifejtését, meghatározott szempontok szerinti taglalását, esetleg egy történet elmondását, annak értelmezését jelöli. Végső soron narratíva. A narratíva kommunikatív megnyilatkozási forma, amelynek jellemzője a klasszikus (leíró) elbeszélésmód, az ok-okozatiság tükröztetése, esetenként a problémamegoldó elbeszélésmód (Bruner 1994; Neisser 1994). További fontos vonása, hogy a narratívában az eseményeket időrendben közlik, a cselekményszálak összefüzése mellett jellemző az elbeszélés információinak rendszerezése és közlése, valamint az elbeszélő szerepe az információk átadásában (Van Dijk 1980; Pléh 1986).

A spontán beszéd és a tanórai narratíva tehát a beszéd tervezési szakaszainak és az artikulációs szakasznak a figyelembevétele alapján eltérnek. Amíg a spontán beszédben mint láttuk - a tervezés (szövegalkotás/akció) és a kivitelezés (szövegmondás/produkció) szinte azonos időben zajlanak, addig ez nem mondható el a tanórai narratíváról, ami félreproduktív vagy interpretatív szöveg. A spontán beszédben a gondolatok megtervezésének makroszintjén a gondolatok összegyüjtése, rendezése, a sorrendiségnek megalkotása, valamint a mikrotervezés szintjén a megfelelő nyelvi forma kialakítása, illetve a kivitelezés folyamatában a létrehozott produktum meghangosítása egyidejű működéseket jelent a beszélő számára. Ugyanakkor a tanórai narratívákban a tervezés időben megelőzi a kivitelezést. A tervezés jól körülhatárolható, hiszen a téma ismert/adott, de a nyelvi forma, s annak szerkezete is, hiszen a narratíva kötött szerkezeti jellemzőkkel bír. A kivitelezés ezúttal is az adott időpillanatban történik, így az elbeszélő szerepe az ismert nyelvi forma tolmácsolásában figyelembe veendő, ami a pillanatnyi helyzet függvénye.

Mindezekből kiindulóan a jelen kutatási kérdés az, miként alakul a kétféle beszédhelyzetben a tervezési és a kivitelezési folyamat egy adott életkort figyelembe véve. A kétféle beszédhelyzetben megalkotott szövegek tehát milyen mennyiségi és minőségi paraméterekkel jellemezhetők. További vizsgálandó kérdés, hogy milyen azonosságok és különbségek mutatkoznak a kétféle beszédhelyzethez kapcsolt szövegekben szegmentális és szupraszegmentális szinten.

Hipotézisünk szerint a kétféle beszédhelyzet másféle tervezési folyamatokat feltételez, ami a szövegek mennyiségi és minőségi paramétereiben egyaránt tükröződik. A tanórai 
kötött témáról szóló narratíva nehezebb feladat, s a nehézség a szegmentális és a szupraszegmentális szinten is követhető. A szegmentális szinten a szövegek szógazdagságában, a szövegeket felépítő szerkezetek típusainak más arányában és a közlésegységek fejlődési mutatójának különbözőségében egyaránt mutatkozik az eltérés. Szupraszegmentális szinten a különbség a szövegek elmondását kifejező lassúbb beszédtempóban és artikulációs tempóban, a szünetek eloszlásában és a szünetek tipizálásakor is jelentkezik.

\section{Anyag, módszer, kísérleti személyek}

A hipotézis ellenőrzésére kísérletet végeztünk. A mai digitális generáció tagjaitól tanórai narratívákat és spontán narratívákat rögzítettünk digitális formában. A tanórai narratívák szóbeli feleletek, amelyek esetén a diákok egy-egy korábban tanult témakörből beszéltek a megadott szempont alapján. Természetesen - feleletekről lévén szó - esetenként a tanári kérdések megválaszolását is rögzítettük, de az elemzésben ezeket a részeket nem vettük figyelembe. A spontán narratívák témaköre valamennyi diák esetében hasonló volt, a tanulók kedvenc időtöltésükről, szabad idejükről meséltek. Valamennyi diáktól 2-3 percnyi beszédeket, többnyire monológokat vettünk fel. Ha elakadtak, egy-egy segítő kérdést kaphattak, hogy folytathassák monológjaikat.

A beszédeket lejegyeztük, majd a Praat program (Boersma-Weenink 2018) segítségével felcímkéztük, megállapítottuk a szüneteket, tipizáltuk azokat, megmértük időtartamukat. Kiszámoltuk a beszédtempókat és az artikulációs tempó adatokat. A szövegek szógazdagságát a type/token (típus/példány) arány segítségével határoztuk meg, tehát a lexémák (type) és a szóelőfordulások (token) arányát számoltuk ki. A kapott százalékos érték arra mutat rá, hogy a narratívák hány százaléka különböző lexéma. A szövegek szintaktikai- grammatikai komplexitását a KFM-mutató alapján számítottuk (GerebennéGósy-Laczkó 1992). Ez az amerikai Lee és Canternek (1971) a hetvenes években kidolgozott DSS-nek (Developmental Sentence Score) nevezett kritériumrendszer magyar adaptációja. A módszer vizsgálja a gyermekek beszédében található mondatok hosszúságát, szerkezetét, a szófajok közül a névmások, a számnevek, a névutók, a határozószók elsajátításának a szintjét, az igeidők és az igeragozás összefüggését, a bővítmények elsajátítását és alkalmazását. A módszer lényege, hogy a spontán beszéd szavai, szerkezetei és grammatikailag helyes, illetve helytelen mondatai meghatározott pontértéket kapnak. A pontozás figyelembe veszi a magyar nyelvtan specifikus jellemzőit, és a magyar gyermek anyanyelv-elsajátítási fázisait és jellemzőit. Így egyes szófajok (fönév, ige) nem kapnak pontot, míg a névmások, számnevek, határozószók, névutók és kötőszók igen, és a különböző szófajok más-más pontot érnek attól függően, hogy mennyire bonyolult és milyen későn jelenik meg az anyanyelv-elsajátítás folyamán. Az igeragozásban szintén az egyszerủbb formák kapnak kevesebb pontot és többet a bonyolult formák, és hasonlóképpen ehhez, a szerkezetek értékelésében is a fokozatosság érvényesül. Az eljárásban a grammatikailag helyes mondatok kapnak pontot szemben a grammatikailag 
helytelen mondatokkal. A KFM-értéket úgy kapjuk meg, hogy a szavak és a szerkezetek értékeléséből kapott pontszámhoz hozzáadjuk a nyelvtanilag helyes mondatok számát, majd a kapott összeget el kell osztani az összes mondat számával.

A vizsgálatban részt vevő diákok átlagéletkora 15,4 év és 17,2 év. A fiatalabb diákok a középiskola 9. évfolyamán, az idősebb diákok a 11. évfolyamon tanulnak. A jelen munkában 5-5 diák spontán és tanórai anyagát dolgoztuk fel mind a két évfolyamon, $s$ minden esetben ugyanazok a diákok szerepeltek a spontán vizsgálatban és a tanórai vizsgálatban is. Valamennyi részt vevő tanuló ép értelmű, ép hallású, egynyelvű (anyanyelve a magyar), nyelvjárást nem beszélnek és mindannyian ugyanabban az iskolában tanulnak. A diákok többsége Pest megyében él, egy részük Budapesten. Iskolatípusuk szakgimnázium.

A rögzített beszédidő mind a tanórai, mind a spontán beszéd felvételek esetén közel azonos volt. A tanórai felvételek ideje a 15 éveseknél 8 perc 27 mp, a 17 éveseknél 8 perc 42,7 mp, a spontán beszéd ideje a 15 éveseknél 10 perc $46,6 \mathrm{mp}$, a 17 éveseknél 10 perc, 44,8 mp. Így az egy före eső beszédidők is közel azonosak, a tanórai felvételek esetén közel 2 percnyiek, míg a spontán beszédben a 2 perces átlagértéket kissé meghaladják a korcsoportokban.

\section{Eredmények}

\subsection{A tanórai és a spontán beszéd szegmentális adatai}

Azt, hogy a kétféle szituációban elmondott narratívákban milyen az alkalmazott lexémák változatossága, vagyis miképpen alakul a szövegek szógazdagsága, a type/token (típus/példány) index számításával állapítottam meg. Az index alapján kapott százalékos értékkel meghatározható, hogy a különböző beszédhelyzetekben létrehozott narratívákban mekkora a különböző lexémák aránya. Így a magasabb érték azt jelzi, hogy a tanuló a narratívájában többféle szótári szót használ. Minthogy a lexémák ismétlődése a szövegek hosszával párhuzamosan növekszik, ezért csak azonos hosszúságú szövegek hasonlíthatók össze.

Mind a tanórai, mind a spontán szövegek rendkívül változatos hosszúságúak voltak. A 17 évesek csoportjában voltak olyanok, akiknél a tanórai feleletek szövege csupán valamivel a 100 szót haladta meg (104 szó), míg a spontán beszédben 300 szavas narratíva is volt (az említett értékek ugyanazon diák esetében fordultak elö). A 15 éveseknél 124 szóelőfordulás volt a legkevesebb a tanórai narratívákban és 125 a spontán beszédben. Ezért a type/token indexet 100 szóra vetítve adtam meg, s ehhez minden diáktól a monológok első 100 szavát vettem figyelembe. Ezért a jelen vizsgálatban kapott érték természetesen magasabb lehet, mint 200 szavas beszédben, amit más kutatások igazoltak (Koizumi-In'nami 2012), ám az összevetéskor mutatkozó jellemzőket a 100 szóra vetített type/token arány is jól láttatja (1. ábra). 


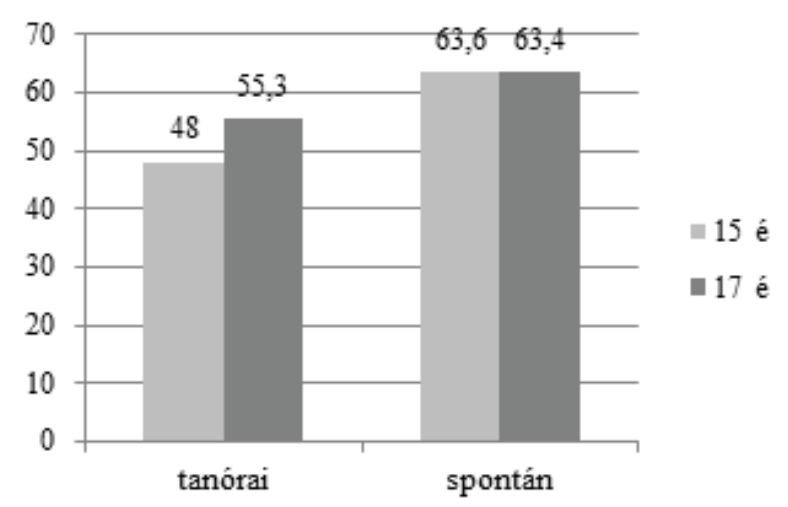

1. ábra: A type/token index értékei (\%)

Az eredmények szerint mind a két korcsoportban hasonló a tendencia, a tanórai narratívákban az átlagos type/token arány kisebb, mint a spontán beszédben, noha a különbségek leíró statisztikai értelemben nem voltak szignifikánsak. A tanórai narratívákban a 15 évesek szövegeinek nem egészen a fele új szótári szó, a 17 évesek szövegeiben pedig a felénél valamivel több a nem ismétlődő szótári szó. A spontán beszédben azonban mind a két korcsoportban a szövegek új szavainak az aránya több mint $63 \%$. Az átlagok tehát azt jelentik, hogy a vizsgált tanulók tanórai narratíváiban sokkal többször ismétlődnek a lexémák, mint amikor a spontán beszédben fejtik ki álláspontjukat egy adott témáról. A feletekben tehát az adott (kötött) téma kifejtéséhez a megfelelő lexémákat megtalálni és előhívni jóval nehezebb feladat számukra, mint a spontán beszédben az adott témáról társalogni.

Ezt az egyéni értékek is alátámasztják, hiszen a tanórai narratívákban a 15 és a 17 évesek csoportjában is hasonlóak a szélső értékek (legalacsonyabb és legmagasabb type/ token arányok), és jóval alacsonyabbak, mint a spontán beszédben. A tanórai narratívákban a 15 évesek csoportjában 41\% és 59\% közöttiek az értékek (szórás: 6,928), a 17 évesek csoportjában 42\% és 60\% közöttiek (szórás: 12,72). A spontán beszédben a 15 évesek értékei 58\% és 70\% közöttiek (szórás: 8,48), a 17 évesekéi 56\% és 74\% (szórás: 12,72) közöttiek.

Elemeztem a diákok szövegeinek grammatikai/szintaktikai szerkesztettségét is a KFM-mutató számításával. Minél magasabb a mutató értéke, annál inkább jelzi azt, hogy az adott tanuló beszédében az anyanyelv-elsajátítás folyamatában később megjelenő és ezért nagyobb pontértéket képviselő szófajok, valamint bonyolultabb ragozási formák biztonsággal használatosak. A tanórai narratívákban a 15 éveseknél átlagosan 21,9 a mutató értéke, a 17 évesek csoportjában pedig 17,98. Az egyéni teljesítményekben nagyok a különbségek, a legkisebb érték a 15 évesek csoportjában 12,95, a legnagyobb 29,84 (szórás: 7,106). A 17 évesek csoportjában nincs ekkora különbség 
a teljesítményekben, a legkisebb KFM-érték 13,04, a legnagyobb 20,88 (szórás: 3,012). A spontán beszédben a 15 évesekre 23,14 a mutató értéke, a 18 éves korcsoportban 30,32. Az egyéni teljesítmények a 15 éves korcsoportban szintén nagyon különbözőek, amit a szórás magas értéke is jelez. A legkisebb KFM-érték 12,65, a legnagyobb ennek közel a háromszorosa 36,7 (szórás: 17,005). A 17 évesek csoportjában szintén nagyok az egyéni eltérések, a legkisebb KFM-érték 18,81, a legnagyobb 52,18 (szórás: 4,5).

A kétféle szituációban szintén a spontán beszédben találtunk nagyobb értékeket (2. ábra), s a tanórai narratívák és a spontán narratívák közti különbség különösen a 17 évesek csoportjában nagy. A statisztikai vizsgálat ezúttal sem mutatott szignifikáns eltérést. Így az eltérés ezúttal is csak tendenciát jelez, azt jelenti, hogy amíg a 15 évesek az egyes szófajokat, morfológiai-szintaktikai sajátságokat (ragozást, szerkezeteket) közel azonos arányban használják a kétféle szituációban elmondott narratíváikban, addig a 17 évesek számára igen nagy kihívást jelent a spontán beszédhez képest a tanórai feleletekben a megfelelő szófajú szavakat, ragozási formákat, igeidőket jól alkalmazni. Vagyis a tanórai narratívákat grammatikailag, szintaktikailag tökéletesen megszerkeszteni sokkal nehezebb számukra, mint ugyanezt megtenni a spontán beszédben.

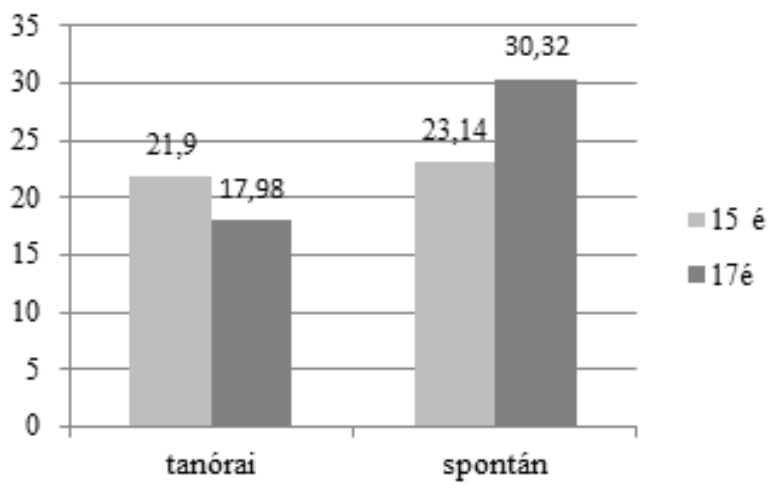

2. ábra: A KFM-mutató értékei

Kérdés, hogy vajon ez a különbség a szerkezetekben, a ragozásban vagy a szófajokban tükröződik-e leginkább, ezért külön megvizsgáltuk azoknak a szerkezeteknek az előfordulását, amelyek a KFM-mutató számításához pontértéket kapnak (3. ábra). 


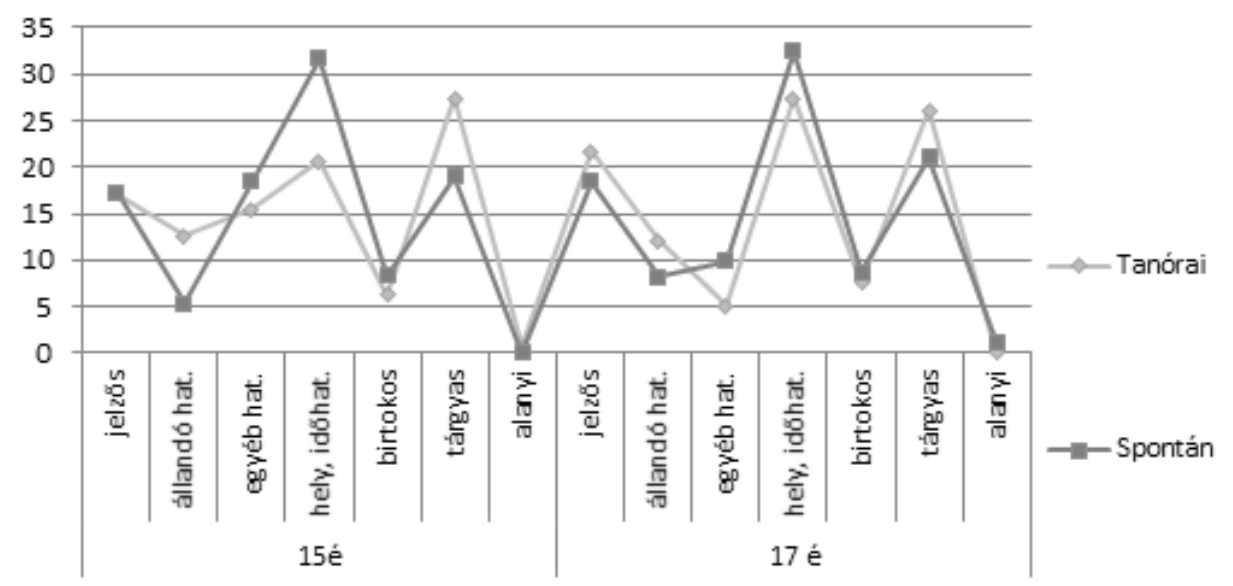

3. ábra: A szerkezetek aránya a narratívákban (\%)

Vélhetően a tanulók kétféle szituációban létrehozott narrativáiban a szövegeket felépítő szintaktikai szerkezetek százalékos megoszlása szintén különbözik egymástól. Az elemzések szerint a tanórai szövegekben a 15 éveseknél a tárgyas szerkezetek emelkednek ki (27,4\%). Hasonló e szerkezetek aránya (26,1\%) a 17 évesek tanórai narratíváiban is, és náluk a helyés időhatározós szerkezetek aránya is ekképpen alakul (27,4\%), ami a 15 éveseknél 20,6\%os előfordulású. A spontán szövegekben azonban mind a két korcsoportban és nagyjából azonos arányban is (15 é.: 31,7\%, 17 é.: 32,5\%) a hely- és időhatározós szerkezetek fordulnak elő a legtöbbször, a tárgyas szerkezetek második helyen állnak a gyakoriságot illetően. Említést érdemel az, hogy a jelzős szerkezetek a tanórai szövegekben inkább a 17 éveseket jellemzik. A szerkezetek előfordulása így azt erősíti meg, hogy a tanórai narratívákban és a spontán beszédben is fóképpen azok az egyszerủ szerkezetek dominálnak a vizsgált tanulók beszédében, amelyek az anyanyelv-elsajátítás folyamatában korábban is jelennek meg.

A szegmentális elemzések szerint tehát a tanórai narratívákban életkortól függetlenül nemcsak több az ismétlődő lexémák aránya, hanem ezek a szövegek grammatikailag és szintaktikailag kevésbé komplex felépítést is mutatnak, ami a 17 évesek csoportjában még inkább igaznak tűnik. A vizsgált tanulók feleletei tehát a spontán beszédhez képest is egyszerűbb felépítésűek, ami minden bizonnyal tanulási nehézségeket jósol.

\subsection{A tanórai és a spontán szövegek temporális adatai}

A tanulók beszédtempó értékeit és artikulációs tempóértékeit a 4. ábra összegzi. A beszédtempó a teljes beszéd sebességét jelenti, azaz az időegység alatt elhangzó beszédjelek (hangok, szótagok, szavak) számát, s ilyenkor a beszédidőbe a szünetek időtartamát beszámítjuk. Az artikulációs tempó a beszédjelek képzésének a sebességét mutatja, tehát az időegység alatt képzett hangok, szótagok, szavak száma a szünetidő nélkül (Gósy 2004: 203). 


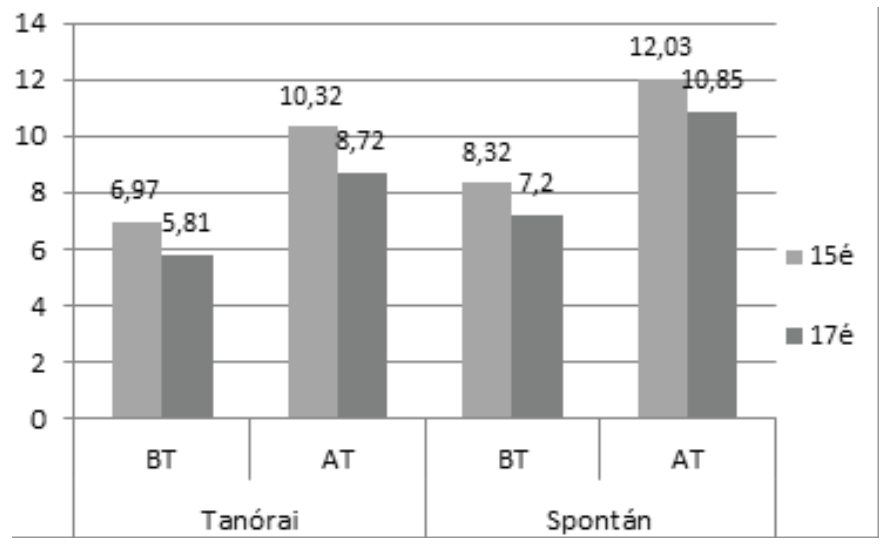

4. ábra: A tempóadatok a tanórai és a spontán narratívákban (hang/sec)

Mindkét korcsoportban azonos volt a tendencia, s az előzetes várakozásainknak megfelelően a tempóértékek a tanórai szövegekben alacsonyabbak voltak, mint a spontán beszédben. A beszédtempó-értékekben (BT) másodpercenként majdnem 1,5 hang, míg az artikulációstempó-értékekben (AT) közel 2 hang a különbség. Az adatok szerint tehát a tanórai narratíva elmondása nagyobb erőfeszítést igényel a diákoknak, mint a spontán beszéd kifejtése. A két korcsoport adatainak egymáshoz viszonyítása az eddigi hasonló életkorú tanulókkal végzett kutatásainkkal (vö. Laczkó 2009, 2019) ellentétes eredményt hozott, hiszen ezúttal az idősebbek tempóértékei voltak alacsonyabbak. E tanulmánynak nem célja e tény okának feltárása, azonban mégis felvetjük lehetőségként és további elemzéseket célozva, hogy vajon ezek a fordított tempóértékek mennyiben lehetnek azzal kapcsolatban, hogy a jelen kutatás valamennyi diákja 2000 után született, és az ún. digitális generáció tagja.

Természetesen az egyéni értékek mind a két korcsoportban és mind a két vizsgált szituációban nagy egyéni eltéréseket mutatnak. A tanórai narratívákban a 15 éves korcsoportban a legkisebb BT-érték 5,4 hang/sec, a legnagyobb 8,91 hang/sec (szórás: 1,296). A 17 évesek között a leglassúbb tempóérték 3,88/hang/sec, a leggyorsabb 6,78 hang/ sec (szórás: 1,462). Az AT szélső értékei a 15 éves korcsoportban 8,53 hang/sec és 12,16 hang/sec közöttiek (szórás: 1,469), míg a 17 évesek csoportjában 5,48 hang/sec és 10,94 hang/sec (szórás: 2,253). A spontán narratívákban a 15 évesek csoportjában a legalacsonyabb BT érték 7,18 hang/sec, a legnagyobb 9,49 hang/sec (szórás: 0,927). A 17 éveseknél 5,71 hang/sec és 9,02 hang/sec (szórás: 1,317). Az AT-értékek a 15 éves csoportban 10,68 hang/sec és 12,88 hang/sec közöttiek (szórás: 0,986), a 17 éves korcsoportban pedig 7,3 hang/sec és 13,25 hang/sec közöttiek (szórás: 2,196). Az egyéni adatok nagy variabilitása szintén azt láttatja, hogy mind a két korcsoportban a tanórai tempóértékek (BT és AT is) sávja alacsonyabb tartományban húzódik, mint a spontán narratíváké. Így a vizsgálatban nemcsak az átlagok, de az egyéni értékek figyelembe vételével is az állapítható meg, hogy 
a tanórai narratívák, jelen esetben a feletetek kialakítása nehezebb erőfeszítést igényel, ami a temporális jellemzőkben a lassúbb tempóértékekben manifesztálódik. Kérdés, hogy vajon mindezek az adatok hogyan függnek össze a kétféle beszédhelyzetekben rögzített szövegek szünetezésével.

A szünetek percenkénti gyakoriságát az 5. ábra mutatja.

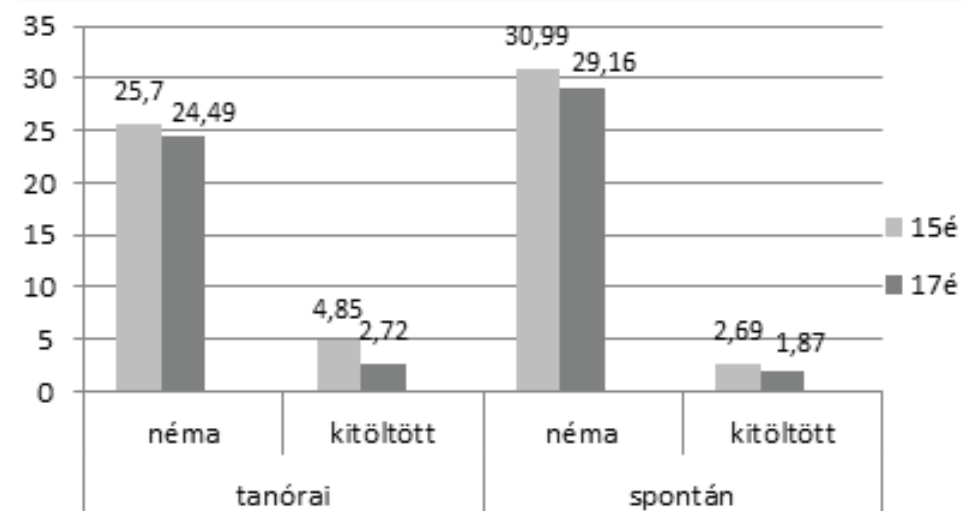

5. ábra: A percenkénti szünetszámok

A tanórai narratívákban a tanulók percenként kevesebb néma szünetet tartottak, mint a spontán beszédben, míg a kitöltött szünetek éppen fordítva alakultak, a percenkénti számok majdnem a duplája a tanórai narratívákban a 15 évesek csoportjában és kb. a másfélszerese a 17 évesek csoportjában.

Az adatok szorosan összefüggnek a kétféle szituációban rögzített szövegek szünetarányaival, a szünetetek számának és időtartamának százalékos arányával (6. ábra).

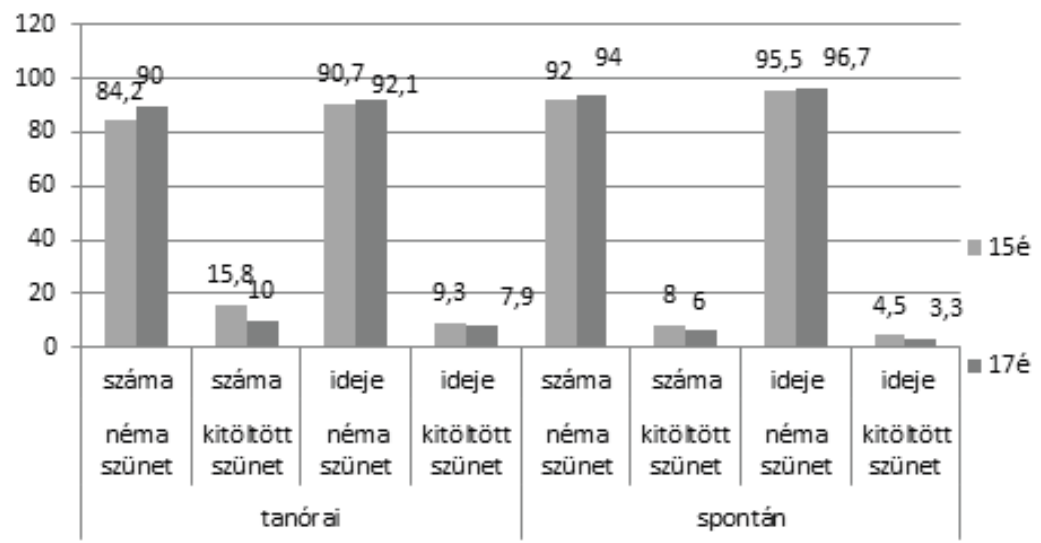

6. ábra: A szünetek számának és időtartamának százalékos aránya 
A néma szünet számának százalékos aránya mind a két korcsoport esetében a spontán beszédben volt magasabb. A növekedés fóképpen a 15 évesek csoportjában látható, akinél 8\%-kal volt több a szünet aránya átlagosan a spontán beszédben a tanórán tapasztaltakhoz képest. A kitöltött szünet számának százalékos eloszlása azonban a tanórai narratívákban volt több, a 15 éveseknél a spontán beszédben tapasztalt előforduláshoz képest majdnem a duplája, míg a 17 évesek csoportjában körülbelül a másfélszerese. A korcsoportok egymáshoz képesti viszonyításakor a szünetek számának alakulása a spontán beszédben közel egyező, a tanórai narratívákban azonban a néma szünetek a 15 éveseknél kisebb arányúak, míg a kitöltött szünetek náluk fordulnak elő nagyobb arányban.

A szünetek idejének alakulása azt láttatja, hogy a spontán beszédben a néma szünetek ideje közel 96-97 százalékos, és jóval kisebb a kitöltött szünetek ideje, 4,5\%, illetve 3,3\%. Mind a két korcsoport tanórai narratíváiban kisebb arányú a néma szünet időtartama, a kitöltött szüneteké pedig a spontán beszédben tapasztaltakhoz képest a duplájára növekszik.

A kétféle szünettípus hossza (7. ábra) is eltérően alakult a kétféle szövegben. Mindkét korcsoportban azonos a tendencia: a tanórai narratívákban a néma szünet és a kitöltött szünet is jóval hosszabb, mint a spontán beszédben. A tanórai narratívákban a 15 évesek korcsoportjában a néma szünetek 140 ms-mal hosszabbak a spontán beszédben tartott néma szünetekhez képest. A 17 évesek csoportjában a különbség nagyjából 100 ms. A kitöltött szünetek időtartamában főleg az idősebbek csoportjában mutatkoznak az eltérések. Náluk a tanórai narratívákban nagyjából 130 ms-mal hosszabbak a kitöltött szünetek a spontán beszédben találhatókhoz viszonyítva. A 15 éveseknél a különbség kisebb, 80 ms. A különbségek leíró statisztikai értelemben szignifikánsak. Párosított T-próba $\mathrm{t}(3)=4,205, \mathrm{p}=0,025)$.

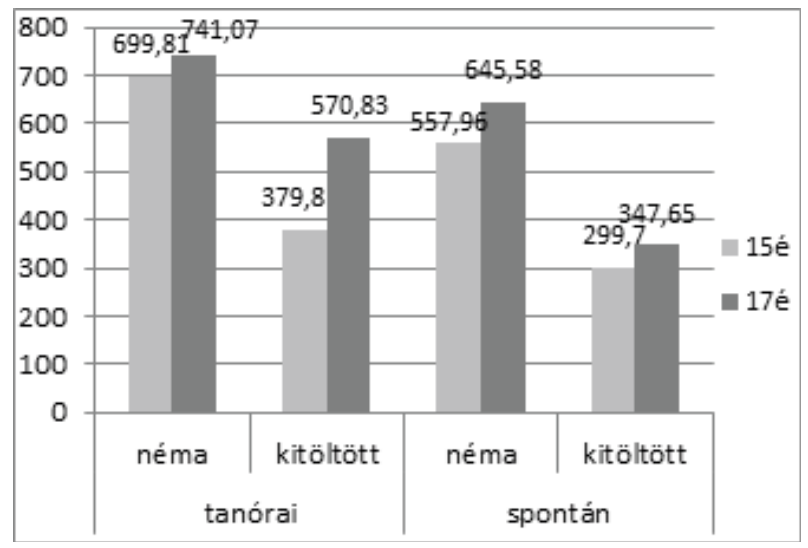

7. ábra: A szünetek típusainak hossza (ms) 
A temporális elemezések eredményei szerint tehát a tanórai narratívákban lassúbb a beszéd és az artikulációs tempó is mind a két korcsoportban, mint a spontán beszédben. A lassúbb tempóértékek egyrészt a percenként tartott kevesebb néma szünettel és több kitöltött szünettel függnek össze, másrészt a szünettípusok idejének eltérő százalékos arányával. A tanórai narratívákat a néma szünetek idejének kisebb százalékos aránya és a kitöltött szünetek idejének nagyobb aránya jellemzi. A tanórai narratívák kevesebb néma szünete ugyanakkor hosszabb időtartamban realizálódik, de a kitöltött szünet is hosszabb, mint a spontán beszédben. A temporális elemzések tehát azt sejtetik, hogy a tanórai narratíva- jelen esetben felelet- megalkotása nehézséget jelent a diákoknak, ami a lassúbb tempóértékek mellett a hosszabb szünettípusokkal együtt jelenik meg.

\section{4. Összefoglalás, következtetések}

A jelen munka célja az volt, hogy középiskolás diákok tanórai narratíváit és spontán narratíváit vesse össze a szegmentális és szupraszegmentális elemzések alapján. Kiinduló hipotézisünk szerint ugyanis a kétféle beszédhelyzetben megalkotott narratíva más-más beszédtervezési folyamatot igényel és így nem azonos nehézségi fokot jelent a tanulóknak. A tanórai feleletek mint narratívák létrehozásának nehézsége szegmentális szinten és szupraszegmentális szinten egyaránt követhető. A kétféle beszédhelyzetben megalkotott szövegek beszédtervezési nehézségei szegmentális szinten a szövegek szógazdagságának és a morfológiai-szintaktikai felépítés különbözőségében, szupraszegmentális szinten pedig a temporális eltérésekben és a tempót alakító szünetezésben manifesztálódik.

A vizsgálat eredményei valamennyi hipotézist alátámasztottak. Szegmentális szinten a tanórai szövegek és a spontán beszéd szógazdagsága közötti eltérést a tanórai szövegek alacsonyabb type/token indexei mutatták a korcsoportokban. A spontán beszédhez képesti alacsonyabb értékek azt a tendenciát láttatják, hogy a tanórai narratívák megtervezése és kivitelezése a vizsgálat diákjai számára összetett feladat. A tanulók az adott témához kötődően nehezebben tudtak különböző szótári szavakat előhívni, így több volt náluk az ismételt lexémák aránya, mint a spontán szövegekben. Ez az eredmény már önmagában is figyelemre méltó, hiszen jelzi/jelezheti a szókincs hiányosságait a tanulóknál, végső soron az olvasás hiányát és az ennek következtében fellépő tanulási problémákat. Ha meggondoljuk azt is, hogy a jelen vizsgálat tanórai narratíváiban minden esetben időbeliséget tükröző narratívák kialakítását kértük, akkor az olvasottsággal és annak következményeként a diákok mentális lexikonának nagyságára vonatkozó sejtésünk megerősödhet. A vizsgálatban részt vevő diákok szakgimnáziumi tanulók ugyan, így az a kérdés is felvetődik, hogy vajon más iskolatípus diákjai esetében miképpen alakulna a szövegek szógazdagságát mérő mutató.

A narratívák grammatikai-szintaktikai komplexitását mérő KFM-érték szintén azt láttatta, hogy a tanórai szövegekben a KFM-mutató mind a két korcsoportban alacsonyabb, mint a spontán beszédben. A spontán beszédre kapott értékek korábbi hasonló 
vizsgálatok (Neuberger 2014; Laczkó 2018) értékeivel mutatnak rokonságot, így a tanórai narratívákban kapott mutatók még inkább alátámasztják e szövegek kevésbé komplex voltát, olykor a spontán beszédhez képest is egyszerübb szerkesztést és felépítést. A tanórai narratívákban előforduló szerkezetek között mind a két korcsoportban szintén az egyszerűbb nyelvi formára utaló tárgyas szerkezetek emelkedtek ki. Csakúgy, mint a spontán beszédben, ahol ugyan a hely- és időhatározós szerkezetek voltak a legnagyobb arányúak, ám ezek is az anyanyelv-elsajátítás folyamatában már korán megjelennek, így az egyszerűbb nyelvi formát igazolják. A szegmentális elemzések eredményei tehát azt sejtetik, hogy a vizsgálatban részt vevő diákok nyelvi, kifejezési nehézségei, amelyek a tanórai feleletekben/narratíváikban is nyomon követhetőek voltak, tanulási nehézségeikkel is szorosan összefüggésben lehetnek.

Mindezeket a szupraszegmentális szintű elemzések is megerősítették. A kétféle szituációban megalkotott szövegeik tempóértékei jelentősen eltértek. A tanórai szövegek sokkal lassúbb tempóértékei a szünetek típusainak másfajta arányával, köztük a kitöltött szünetek számának növekedésével, valamint a szünetfajták időtartamának alakulásával, így a spontán beszédhez képesti hosszabb időtartamban realizálódó néma szünetek és kitöltött szünetekkel hozhatók összefüggésbe. A lassabb tempó és hosszabb szünetek tehát azt jelezhetik, hogy a tanórai narratívákat több különböző lexéma előhívásával és a nagyobb pontértéket jelző, bonyolultabb szerkezetek megtalálásával nem könnyű feladat megtervezni, felépíteni és meghangosítani a feleleteket kísérő szituációkban a tanulóknak. Ez pedig tanulási problémákban is manifesztálódik, amit a gyengébb osztályzataik egyértelmủen alátámasztanak. Kérdés, hogy a vizsgált diákok iskolatípusa mennyiben játszik mindebben szerepet. Vagyis kérdés, hogy a kapott eredmények vajon a gimnáziumba járó hasonló korú digitális nemzedék tagjai körében milyen mértékben mutathatók ki. Ennek megválaszolásához szükséges a jelen vizsgálatot nemcsak nagyobb mintán, de más iskolatípusban tanuló diákokkal is elvégezni.

\section{Irodalom}

Antalné Szabó Ágnes 2006. A tanári beszéd empirikus kutatások tükrében. A Magyar Nyelvtudományi Társaság Kiadványai 225. Budapest: Magyar Nyelvtudományi Társaság.

Antalné Szabó Ágnes 2013. A tanulásalapú anyanyelvi nevelés. Anyanyelv-pedagógia 6/4. http://www.anyanyelv-pedagogia.hu/cikkek.php?id=481 (2019. 04. 11.)

Boersma, Paul - Weenink, David 2018. PRAAT: Doing phonetics by computer. v 6.1. http://www.fon.hum.uva.nl/praat/ (2019. 04. 11.)

Bruner, Jerome 1994. The „remembered” self. In: Neisser, Ulrich - Fivush, Robyn (eds.): The remembering self: Construction and accuracy in the self-narrative. New York: Cambridge University Press. 41-54. https://doi.org/10.1017/CBO9780511752858.005 
Gerebenné Várbíró Katalin - Gósy Mária - Laczkó Mária 1992. Spontán beszéd megnyilvánulások szintaktikai elemzése DSS technika elemzésével. Kézirat. Budapest.

Gósy Mária 2002. A megakadásjelenségek eredete a beszédprodukció tervezési folyamatában. Magyar Nyelvör 126/2: 192-203.

Gósy Mária 2004. Fonetika, a beszéd tudománya. Budapest: Osiris Kiadó.

Gyarmathy Dorottya 2009. A beszélö bizonytalanságának jelzései: ismétlések és újraindítások. Beszédkutatás 17: 196-216.

Harley, Trevor 2001. The Psychology of Language. New York: Taylor and Francis. https://doi.org/10.4324/9780203345979

Koizumi, Rie - In'nami, Yo 2012. Effects of text length on lexical diversity measures: Using short texts with less than 200 tokens. System 40: 554-564. https://doi.org/10.1016/j. system.2012.10.012

Laczkó Mária 2009. Középiskolai tanulók spontán beszédének temporális jellegzetességei. Magyar Nyelvör 133/4: 447-467.

Laczkó Mária 2018. A spontán beszéd grammatikai-szintaktikai szerkesztettsége tizenéves korban. In: Balázs Géza - Lengyel Klára (szerk.): Grammatika és oktatás - idöszerü kérdések Struktúra, funkció, szemiotika hálózat. Budapest: ELTE Mai Magyar Nyelvi Tanszék- Inter (IKU) - Magyar Szemiotikai Társaság. 317-328.

Laczkó, Mária 2019. The Temporal Characteristics of Teenagers in Spontaneous and Rhetorical Speeches. Journal of Linguistics and Literature 3/1: 29-34.

Lee, Laura L.- Canter, Susan M. 1971. Developmental sentence scoring: a clinical procedure for estimating syntactic development in children's spontaneous speech. The Journal of Speech and Hearing Disorders 36/3: 315-340. https://doi.org/10.1044/ jshd.3603.315

Levelt, Wilhelm J. M. 1989. Speaking: from intention to articulation. Cambridge MA: MIT Press.

Neisser, Ulrich 1994. Self-narratives: True and false. In: Neisser, U. - Fivush, R. (ed.): The remembering self: Construction and accuracy in the self-narrative. New York: Cambridge University Press. 1-18. https://doi.org/10.1017/CBO9780511752858.003

Neuberger Tilda 2014. A spontán beszéd sajátosságai gyermekkorban. Budapest: Eötvös Kiadó.

Nooteboom, Sieb 2005. Lexical bias revisited: Detecting, rejecting and repairing speech errors in inner speech. Speech Communication 47: 43-48. https://doi.org/10.1016/ j.specom.2005.02.003

Pléh Csaba 1986. A történetszerkezet és az emlékezeti sémák. Budapest: Akadémiai Kiadó. Postma, Albert - Kolk, Herman - Povel, Dirk-Jan 1990. On the relation among speech errors, disfluencies and self-repairs. Language and Speech 33: 19-29. https://doi. org/10.1177/002383099003300102 
Shriberg, Elizabeth 2001. To „errrr” is human: ecology and acoustic of speech disfluencies. Journal of the International Phonetic Association 31: 153-69. https://doi.org/10.1017/ S0025100301001128

Van Dijk, Teun 1980. Macrostructures. An Interdisciplinary Study of Global Structures in Discourse, Interaction, and Cognition. Hillsdale: Lawrence Erlbaum.

Wacha Imre 1974. Az elhangzó beszéd főbb stíluskategóriáiról. Általános Nyelvészeti Tanulmányok X: 203-216. 